Available Online at https://journal.unismuh.ac.id/index.php/otoritas

Otoritas : Jurnal Ilmu Pemerintahan, 10 (2), October 2020, 132-141

\title{
Ethics of Public Administration in the Era of Technology Disruption and Government Innovation
}

\author{
Lia Muliawaty ${ }^{*}$ ), Dyah Bayu Framesthi ${ }^{2}$ \\ ${ }_{1}^{1}$ Department of Public Administration and Policy, Faculty of Social and Political Sciences, \\ Universitas Pasundan, Jl. Lengkong Besar No. 68, Bandung, 40261, West Java, Indonesia. \\ ${ }^{2}$ Doctoral Program of Social Science, Postgraduate Program, Universitas Pasundan, \\ Jl. Lengkong Besar No. 68, Bandung, 40261, West Java, Indonesia.
}

Received: 6 March 2020; Revised: 24 August 2020; Accepted: 11 October 2020

\begin{abstract}
Good public administration services are the main thing in running a quality government. Therefore, ethics is a major part of maintaining the quality of public administration services, especially in the era of Industry 4.0 which needs to also apply ethics in using technology. The purpose of this study is to examine the formation and implementation of ethics in public administration in the era of government innovation disruption due to technological development and disruption. This research uses a qualitative approach with descriptive analysis method which is sourced from various literature both primary and secondary, then an analysis of the various literature is carried out. Descriptive analysis results show that technology has become an indispensable need in government, in various fields and activities. Where, the disruption of the technology also impacts on various government innovations that really need ethics, especially on public services to avoid mal-administration. The impact of this research is knowledge of the importance of awareness of implementing ethics in public administration services in the era of technological disruption to improve the quality of government services.
\end{abstract}

Keywords: Administration Ethics; Ethics; Government Innovation; Public Administration; Public Service; Technology Disruption

How to Cite: Muliawaty, L., \& Framesthi, D. B. (2020). Ethics of Public Administration in the Era of Technology Disruption and Government Innovation. Otoritas : Jurnal Ilmu Pemerintahan, 10(2), 132-141.

Permalink/DOI: https://doi.org/10.26618/ojip.v10i2.3219

${ }^{*}$ Corresponding Author.

E-Mail : lia.muliawaty@unpas.ac.id

Copyright (C) 2020, Otoritas : Jurnal Ilmu Pemerintahan, ISSN: 2088-3706 (Print), ISSN: 2502-9320 (Online) 


\section{INTRODUCTION}

Ethics can be defined as a set of values in the form of guidelines, references, guidelines for what must be done in carrying out their duties, but also also functions as a standard to assess whether the nature, behavior, or actions in carrying out their duties are considered good or bad. Ethics is very closely related to how a human behavior can be accounted for in carrying out the tasks that exist in public administration (Brands \& Kleinman, 2010; K. G. Denhardt, 1988; R. B. Denhardt \& Denhardt, 2000; Ibrahim, 2008; Maani, 2010; Plant, 2018). In this embodiment of responsibility ethics must not be abandoned and indeed must be used as a guide for behavior (Holilah, 2013; Pasolong, 2008; Santoso \& Dewi, 2019). Whereas disruption is defined as being removed from the root. If interpreted in daily life, disruption is a fundamental change (Kilkki, Mäntylä, Karhu, Hämmäinen, \& Ailisto, 2018).

Public administration or can be called public bureaucracy is a state institution that carries the mission of fulfilling the public interest which is claimed to be responsible for the public it serves (Handayaningrat, 1996; Pasolong, 2008). The public bureaucracy that we commonly refer to as government is essentially service to the community. Government is not held to serve themselves, but to serve the community and create conditions that allow each member of the community to develop their abilities and creativity in order to achieve common goals (Rasyid, 1998).

Industrial Revolution Era 4.0 gave birth to an era of disruption where the internet of things became a basic need that triggered massive innovations in the economic, social and even political life of a community (Ristiandy, 2020). There was a big change in the social and economic order of the community and naturally it was also followed by the govern- ment, as the authority that regulates the course of the life of the citizens.

In the digital era, as the Indonesian people are being confronted with the disruption of digital innovation, the government has encouraged people to be more politically literate, more selective in choosing leaders and more aware of datafacts that can be easily accessed. This situation makes there information that can be spread quickly, the freedom of the press, so that all information and data can be directly received by the public in real time. These things make people more aware of the importance of their involvement in creating chages to organize a better nation's future.

Many developed countries have made use of advances in digital technology in combating corruption and improving their governance systems (Baktybayev, 2020; Dyussenov, 2019). Because with the implementation of this digital innovation solution facilitates services, cuts bureaucracy, while preventing and reducing extortion and corruption practices, but there are still problems that will arise in its application in Indonesia to be applied successfully (Suherry, 2017), especially in other regions that are not yet advanced in cities. big cities with the strength of their human resources and expertise in mastering the technology. This is evident in the fact that occurred in 2018, the success of the Corruption Eradication Commission (Komisi Pemberantasan Korupsi) of 30 Hand-catch Operation (highest achievement), 256 people were named as suspects of corruption, and among them 26 people were regional heads.

In the digital era like today, in the 2018 Global Digital Report, it is mentioned that internet users in Indonesia reached 132 million people or around $50 \%$ of the population, with an average internet usage duration of 8 hours 51 minutes per person every day (Buhalis et al., 2019). This indirectly changed the way 
the government communicates with the people to change very quickly. With the use of digital innovation multi-step communication models with a variety of channeled digital disruption in government also has a positive impact to improve the quality of public services (Supardal, 2016). This is due to the application of digital technology so that the process of public and government services becomes easier, faster and cheaper. Including better effectiveness in terms of control and supervision.

From the point of life that moves dynamically, the life of administrative ethics is expected to move in accordance with the times (Songklin, 2017). In the current situation, namely in the era of disruption or millennial era, ethical change has shifted and experienced many changes. The current condition of the crisis in Indonesia is felt because of the change in values and norms that should guide someone in the form of a habit that reflects a person's good and bad behavior. In this era of disruption, it is thought to be greatly influenced by technological developments that are increasingly developing. However, in its development this technology has positive and negative impacts. So the purpose of this research is to uncover the ethics of public administration in the era of government innovation disruption.

\section{RESEARCH METHODS}

The method used in this paper is descriptive analysis method. According to Nazir (2003), descriptive method is a method in examining the status of a group of people, an object, a set of conditions, a system of thought or a class of events in the present (Nazir, 2003). The purpose of this descriptive study is to make a systematic, factual and accurate description, description, or painting of the facts, traits and relationships between the phenomena investigated. According to Whitney the descriptive method is the search for facts with the right interpretation. So in other words analytical descriptive research takes the problem or focuses on the problems as they were when the research was carried out, the results of the research are then processed and analyzed to draw conclusions (Whitney, 1960). According to Sugiyono stated that the descriptive method is a method that functions to describe or give an overview of the object under study or collected data as it is without analyzing and making conclusions that are applicable to the public (Sugiyono, 2009).

\section{RESULTS AND DISCUSSION}

Formation and Implementation of Ethics in Public Administration

The ethical values of public administration as depicted become a norm that must be followed and obeyed by every public administrator in carrying out his duties and authorities, it will be able to prevent the emergence of maladministration in various forms, even though there is no oversight body. But this is not enough to guarantee the occurrence of mal-administration within the bureaucracy. There is something more important, namely internal control from the organizer of public administration, in the form of faith and religion that is inherent in someone.

Lewis and Gilman mention that "Ethical values are beliefs about right and wrong. These yardsticks for ethical behavior draw on feeling and thinking" (Lewis \& Gilman, 2005). So when talking about ethical values which is a belief about right and wrong, then at this level, ethical behavior refers to feelings and thoughts.

"But not all values are the same, neither are they necessarily associated with ethical behavior.Some are virtues-the habits of ethical action embedded in moral character that underlie ethical behavior and translate abstract, ethical values into customary, observable behavior. Many ancient traditions stress personal virtue, and 
Available Online at https://journal.unismuh.ac.id/index.php/otoritas

Otoritas : Jurnal Ilmu Pemerintahan, 10 (2), October 2020, 135

Plato wrote of four: courage, wisdom, justice, and moderation."

But not all values are the same, nor do they have to be linked to ethical behavior. Some are virtues - habits of ethical action that are embedded in the moral character that underlies ethical behavior and translates abstract, ethical values into observable and observable behavior. Many ancient traditions emphasize personal virtue, and Plato wrote four: courage, wisdom, justice, and moderation. So personally/individually if the emphasis on ethics can also be influenced by factors of courage, wisdom, justice, and moderations.

Thus it can be concluded that the priority scale for preventing public maladministration is:

1. There needs to be a strong internal control within the public administration organizer, which can form a personality based on faith and religious values;

2. Implementing public administration ethics;

3. Existence of external control in the form of supervision, both political, functional and community supervision.

But it will be far more effective if all three can be applied simultaneously. Thus, mal-administration and all its dimensions can not only be prevented but also eradicated.

Types of Technology Disruption and Government Innovation

Digital innovation technology trends also disrupt community work and lifestyles, among others (Buhalis et al., 2019):

1. Learning in real time, that is the habit of learning online anywhere and anytime including education technology (edtech). In 2019 learning informally utilizing digital platforms will be more massive in its movements.
2. Power to the people, namely the opportunity and possibility to buy products directly between buyers and sellers through digital platforms.

3. The end of fixed job, meaning special abilities or skills are key to getting a job.

The current trend is that the government has succeeded in using social media not only to interact with citizens. But also to involve and empower the community. In 2020, the scenario developed is to utilize social media as a provider of audience data, to help the government analyze the level of sentiment, developing opinions, and track feedback on the effectiveness of public policies and services in various regions. Between 2020-2030, policymakers will apply the 'agile software development model' to government policy products. Including making prototypes, pilot projects, and trial programs.

In 2030 the scenario developed by the government is to build a platform to ensure partner accountability and manage crowdsourcing Campaigns. Crowdsourcing is a term to describe a process in managing work projects to get funding from citizens in large quantities through online facilities.

In 2050, operational shortcomings will be overcome by inputting technology utilization and community empowerment. One online space for all services, one government office in each region, and a lean bureaucracy. In addition, trends in the innovation scenario and development of digital technology in global government management include: triple bottom line for performance evaluation; collaborative governance; data-based policies; society is consumer/ client; cloud states; data transparency; digital divide and privacy; public service; public self-service; unlimited public service; innovative pricing model; an aging population; population declined in western countries; population growth in the east; women's socioeco- 
nomic status; increasing the big cities; smart city; arcologi; sharing the economy; vehicle without driver; flying cars; unmanned aircraft; improvement of infrastructure congestion; hyperloop; digital currency; open banking; digital sequrity; cyber security; $5 \mathrm{G}$ mobile provider; blockchain; internet of things, artificial intelligent, and so on (Dawes, 2009).

Administrative Ethics in Government Innovation Disruption

The current era of disruption is marked by the presence of various innovations, technologies, platforms, and also new business models. The government, business actors, and the public are also required to respond positively if they want to continue to survive and continue to grow. The government is advised to make regulations that are in line with each development, so that they can be in line with technological developments and innovations that are happening. Meanwhile, business actors are demanded to be more adaptive in responding to any changes that occur, so that they are not left behind and continue to develop their business.

Disruption can be seen as something positive because it is a dynamic innovation. This condition is a phenomenon that the administration of the government must also disrupt the old pattern that has been outdated. The administration which is more conventional and conservative seems to be overhauled in order to be able to provide better services and provide solutions to problems faced both at the center and in the regions.

In the administration of the State, innovation must continue to be encouraged so that problems in public services can be overcome, and therefore the concept of sustaining innovation that was first introduced in the business world must also be applied to the administration of the State. Leaders are an important part that is very influential with the sus- tainability of sustaining innovation because it is required to think creatively. In the current era of globalization, the spirit of entrepreneurship must exist in the concept of running the State, because the collaborative relationship of innovation created by the business and government sectors is inseparable and interrelated with one another.

Referring to the Organization for Economic Co-operation and Development (OECD, 2000) states that "public services are public trust" (Lewis \& Gilman, 2005). Citizens hope that public servants or ASN can serve the public interest fairly and manage public resources well every day. Fair and reliable public services inspire public trust. "The ethics of public service is a prerequisite for, and supporting, public trust, and is a keystone of good governance."

Sustaining innovation is divided into several levels to monitor its development, among others (Putra, 2018):

1. Re-Design: redesign existing products by limiting technical improvements;

2. Product Alternatives: conceptualize new products or new services to meet the ever-increasing and complex functional needs;

3. System: designing systems for the needs of increasingly moving and complex communities.

With the disruption of government supported by technological sophistication, it makes life easier for humans. Since the reform was initiated, the concept of good governance has become the main objective of the government. The New Public Service Theory is very instrumental in the formation of this era of disruption where in the service carried does not look at the economic or social side.

The innovations presented by the government are indeed important but not enough. Other pre-conditions that encourage government disruption are so that people do not wait too long for their 
welfare, such as (Offe, 2008):

1. One Government Mind

It is not right if the executive and legislative are "cool and calm" for a public policy, but there is too much debate without a clear vision to make public policy only become pulp. All elements of government must agree on the same vision for the common welfare, remember deliberation and consensus as the nation's values.

\section{One Equity of Government}

The Republic clearly needs the same standard, there are already standards that do not apply the same, some are very capable of carrying out until they are completely unable. Even the current minimum service standards and public service standards are not meant to be leveling but only to obey rules. Not to mention the dominance of the economic pie, the government must interfere in clearing the gap to even the economy.

\section{One Gate of Government}

The current government is known for its high fragmentation, different administrative institutions, poor communication and coordination. As a result, residents have neglected their public services. The need for the presence of the State in a gate that is equal to the integration of public services.

These three things are prerequisites to governing the government at various levels, besides the multiplier effect will occur such as creating a conducive climate that can open total disruption in various other sectors. Unfortunately we need to understand that the context of the public sector is very different from the private sector. The public sector has public values such as transparency and accountability which will certainly reduce the speed of disruption. As ordinary citizens, we must participate by being accustomed to change, which is adaptive to change and not allergic to change.

The development of the application of public service delivery as happened in
Indonesia, is also an affirmation that people's lives have fundamentally changed. This shows that all must be prepared with the Industrial Revolution 4.0, including the readiness of the State Civil Apparatus as the state apparatus (Ristiandy, 2020). In the delivery of public services, especially in Indonesia, moral and ethical violations can be observed starting from the beginning of the public policy process (proposing programs, projects, and activities that are not based on reality), the design of public service organizations (structural arrangements, formalization, dispersion of authority) very biased against certain interests, the process of management of public services that is full of engineering and camouflage (ranging from technical planning, financial management, human resources, information, etc.), all of which appear from the characteristics of not transparent, not responsive, not accountable, not fair, and so on. And undeniably, all moral and ethical violations have been revealed as one of the causes of the weakening of our government.

The development trend of our current government is actually in phase 4.0. consisting of (Setiyono \& Atmojo, 2014):

1. The first phase, is the phase where the government is dominated by an absolute monarchic phase, where the government runs as a regulator of the people and government officials devote their lives to royal power and the nobility.

2. Second phase, the consolidation phase of democracy. This phase, which was formed between the French Revolution and after the Second World War, was the phase where the government was mostly in the form of a republic.

3. The third phase, is the marketisation phase of the role of government in which the role of government is significantly reduced in regulating the social and economic life of the people. Free market patterns dominate in this 
phase.

4. The fourth phase, is the phase of entrepreneurship government. This phase is a continuation of the third phase where managerial reforms are also carried out by changing the mindset and work culture. Famous concepts from the fourth phase are New Public Management by Christopher Hood and Entrepreneurial Government by Osborne and Gaebler. Phase 4.0 is what deserves to be called the Disruption Government phase.

Disruption government is a synergy between the industrial revolution 4.0 and the fourth phase of bureaucratic evolution. To realize disruption government, it is necessary to adopt entrepreneurial values in carrying out bureaucratic activities. Conservative bureaucratic values such as legal-formal, hierarchical, and procedure are replaced by new values such as flexibility, performance-based pay, competition and essence. The consequence of the enforcement of these entrepreneurship values is the abolition of the Weber bureaucratic model which tends to be rigid and formal (Ristiandy, 2020). Disruption government will provide major changes in the government management system which will have an impact on the reduction of legal rules, procedures and the elimination of the hierarchical system. ASNs are not required to fulfill working hours quantitatively, but are given measurable, clear and specific performance targets as well as fair and promising compensation and reward systems to maintain the talents they have in an organization.

Ethics are often seen as an element that is less related to the world of public service. In fact, in the literature on public services and public administration, ethics is one of the elements that largely determines the public satisfaction served as well as the success of the public service organization itself. Flexibility needs to be given to every member of the organization with the help of information technology, so that they can work without having to be bound by the conditions of space and time at work. The leniency given to bureaucracy in the era of disruption government requires the government to have employees with strong morality. This morality contains characters with integrity, honesty, unyielding spirit, and high idealism. Disruption government, obviously, does not provide a place for employees with pragmatic characteristics, who must be disrupted from the bureaucratic tree, because they are busy gaining illegal profits from budget management.

\section{CONCLUSION}

The ethics of public administration in this era of government innovation disruption is a priority scale to prevent maladministration. This encourages the need for strong internal control within the public administration organizers, which can form personalities based on faith and religious values, and implement public administration ethics. Then, there needs to be external control in the form of supervision, both political, functional and community supervision.

Industrial Revolution Era 4.0 gave birth to an era of disruption (disruption era) where the internet of things became a basic necessity that triggered massive innovations in the economic, social and even political life of a community. The current era of disruption is marked by the presence of various innovations, technologies, platforms, and also new business models. The government, business actors, and the public are also required to respond positively if they want to continue to survive and continue to grow. The government is advised to make regulations that are in line with each development, so they can be in line with technological developments and innovations that are happening. Whereas business actors are demanded to be more adaptive in respond- 
ing to any changes that occur, so that they are not left behind and continue to develop their business. Disruption can be seen as something positive because it is a dynamic innovation. This condition is a phenomenon that the administration of the government must also disrupt the old pattern that has been outdated. The administration which is more conventional and conservative seems to be overhauled in order to be able to provide better services and provide solutions to problems faced both at the center and in the regions.

Ethics are often seen as an element that is less related to the world of public service. In fact, in the literature on public services and public administration, ethics is one of the elements that largely determines the public satisfaction served as well as the success of the public service organization itself. Flexibility needs to be given to every member of the organization (ASN) with the help of information technology, so that they can work without having to be bound by the conditions of space and time at work. The leniency given to bureaucracy in the era of disruption government requires the government to have employees with strong morality. This morality contains characters with integrity, honesty, unyielding spirit, and high idealism. Disruption government, obviously, does not provide a place for employees with pragmatic characteristics, who must be disrupted from the bureaucratic tree, because they are busy gaining illegal profits from budget management.

\section{ACKNOWLEDGEMENT}

The authors acknowledge and thank Universitas Pasundan, Indonesia for the facility and financial support for this work.

\section{REFERENCES}

Baktybayev, B. (2020). Analysis of the Relationship between Women's Participation and the Rate of
Corruption in the Post-Soviet States. Journal of Contemporary Governance and Public Policy, 1(1). https://doi.org/https:// doi.org/10.46507/jcgpp.v1i1.3

Brands, R. F., \& Kleinman, M. J. (2010). Robert's Rules of Innovation: A 10Step Program for Corporate Survival. New Jersey: John Wiley \& Sons.

Buhalis, D., Harwood, T., Bogicevic, V., Viglia, G., Beldona, S., \& Hofacker, C. (2019). Technological disruptions in services: lessons from tourism and hospitality. Journal of Service Management, 30 (4), 484-506. https:// doi.org/10.1108/JOSM-12-20180398

Dawes, S. S. (2009). Governance in the digital age: A research and action framework for an uncertain future. Government Information Quarterly, 26(2), 257-264. https://doi.org/10.1016/ j.giq.2008.12.003

Denhardt, K. G. (1988). The ethics of public service: Resolving moral dilemmas in public organizations. Connecticut: Greenwood Publishing Group.

Denhardt, R. B., \& Denhardt, J. V. (2000). The New Public Service: Serving Rather than Steering. Public Administration Review, 60(6), 549 -559. https:// doi.org/10.1111/00333352.00117

Dyussenov, M. (2019). The Role of ICT in Addressing Corruption Across Political Regimes. Otoritas: Jurnal Ilmu Pemerintahan, 9(1), 42-55. https://doi.org/10.26618/ 
Available Online at https://journal.unismuh.ac.id/index.php/otoritas

Otoritas : Jurnal Ilmu Pemerintahan, 10 (2), October 2020, 140

ojip.v9i1.1508

Handayaningrat, S. (1996). Pengantar Studi Ilmu Administrasi \& Manajemen. Jakarta: Gunung Agung.

Holilah, H. (2013). Etika Administrasi Publik. Jurnal Review Politik, 3(2), 232-255.

Ibrahim, A. (2008). Pokok-Pokok Administrasi Publik \& Implementasinya. Bandung: Refika Aditama.

Kilkki, K., Mäntylä, M., Karhu, K., Hämmäinen, H., \& Ailisto, $\mathrm{H}$. (2018). A disruption Framework. Technological Forecasting and Social Change, 129, 275-284. https://doi.org/10.1016/ j.techfore.2017.09.034

Lewis, C. W., \& Gilman, S. C. (2005). The ethics challenge in public service: $A$ problem-solving guide. New Jersey: John Wiley \& Sons.

Maani, K. D. (2010). Etika pelayanan publik. Jurnal Demokrasi, 9(1).

Nazir, M. (2003). Metode Penelitian. Jakarta: Ghalia Indonesia.

Offe, C. (2008). Contradictions of the Welfare State. Philadelphia: Routledge location.

Pasolong, H. (2008). Teori Administrasi Publik. Bandung: Alfabeta.

Plant, J. F. (2018). Responsibility in Public Administration Ethics. Public Integrity, 20(sup1). https:// doi.org/10.1080/10999922.2017. 1413927

Putra, R. M. D. (2018). Inovasi Pelayanan
Publik Di Era Disrupsi (Studi Tentang Keberlanjutan Inovasi EHealth di Kota Surabaya). Kebijakan Dan Manajemen Publik, $6(2)$.

Rasyid, R. (1998). Desentralisasi dalam menunjang pembangunan daerah dalam pembangunan administrasi di Indonesia. Jakarta: Pustaka LP3ES.

Ristiandy, R. (2020). BUREAUCRATIC DISRUPSION AND THREATS OF UNEMPLOYMENT IN THE INDSUTRI 4.0 REVOLUTION. Journal of Local Government Issues, 3(1). https://doi.org/10.22219/ logos.v3i1.10923

Santoso, T., \& Dewi, M. P. (2019). Etika Aparatur Sipil Negara dalam Membangun Good Governance. Transparansi: Jurnal Ilmiah Ilmu Administrasi, 2(2), 179-187. https://doi.org/10.31334/ transparansi.v2i2.648

Setiyono, B., \& Atmojo, T. (2014). Pemerintahan \& manajemen sektor publik: prinsip-prinsip manajemen pengelolaan negara terkini. Yogyakarta: CAPS (Center of Academic Publishing Service).

Songklin, P. (2017). Ethics in Public Administration: Theoretical Foundation. In Proceedings of the International Conference on Ethics in Governance (ICONEG 2016). Paris, France: Atlantis Press. https://doi.org/10.2991/iconeg16.2017.87

Sugiyono, S. (2009). Metode Penelitian Kuantitatif, Kualitatif, dan R\&D. Bandung: Alfabeta.

Suherry, S. (2017). Politik Pemberantasan 
Available Online at https://journal.unismuh.ac.id/index.php/otoritas

Otoritas : Jurnal Ilmu Pemerintahan, 10 (2), October 2020, 141

Korupsi di Indonesia. Otoritas : Jurnal Ilmu Pemerintahan, 7(1), 46. https://doi.org/10.26618/ ojip.v7i1.417

Supardal, S. (2016). Penerapan ICT dalam Pelayanan Publik di Kabupaten
Bantul. Otoritas: Jurnal Ilmu Pemerintahan, 6(2), 120. https:// doi.org/10.26618/ojip.v6i2.272

Whitney, F. (1960). The elements of research (Asian Edition). New Jersey: Prentice-Hall. 